\title{
Effect of Phototherapy on Serum Calcium and Magnesium Levels in Neonates Receiving Phototherapy for Neonatal Jaundice
}

\author{
Hibatallah A. Elshenawi ${ }^{1}$, Rania E. Abdelatty ${ }^{1}$, Eman R. Abdelgawad ${ }^{2}$, Ismail A. Ramadan ${ }^{1}$ \\ Departments ${ }^{1}$ Pediatrics and ${ }^{2}$ Clinical Pathology, Benha Faculty of Medicine, Benha University, Benha, Egypt \\ *Correspondence author: Hibatallah A. Elshenawi, Mobile: (+20) 01126576769, \\ E-mail: heba.elshenawi@gmail.com
}

\begin{abstract}
Background: Neonatal hyperbilirubinemia is one of the most common newborn entities. Phototherapy has been the therapy of choice for neonates suffering from indirect hyperbilirubinemia. One of the consequences of phototherapy is hypocalcaemia and hypomagnesaemia. Phototherapy leads to inhibition of pineal gland by transcranial illumination resulting in a decline in melatonin level, which leads to increased calcium absorption by bones.

Patients and Methods: This study was conducted on 50 full-term jaundiced neonates ( 23 males \& 27 females) received phototherapy for treatment of neonatal indirect hyperbilirubinemia. Cases were selected from those admitted to NICU of Benha University Hospital. Serum calcium, serum magnesium were measured in their blood samples before phototherapy and after 48 hours and at the end of phototherapy.

Results: In our study hypocalcemia was assessed as a complication of phototherapy in newborns managed for neonatal hyperbilirubinemia as mean calcium was $8.63 \pm 1.54 \mathrm{mg} / \mathrm{dl}$ pre-phototherapy and was $8.22 \pm 1.64 \mathrm{mg} / \mathrm{dl}$ postphototherapy. The difference was as statistically significant $(\mathrm{p}<0.001)$. Calcium level was lower after phototherapy. Pre-phototherapy, $12(24.0 \%)$ showed hypocalcemia $(<8 \mathrm{mg} / \mathrm{dl})$ and $38(76.0 \%)$ showed normal calcium $(>8 \mathrm{md} / \mathrm{dl})$. Post-phototherapy, $19(38.0 \%)$ showed hypocalcemia $(<8 \mathrm{mg} / \mathrm{dl})$ and $31(62.0 \%)$ showed normal calcium $(>8 \mathrm{md} / \mathrm{dl})$. The difference was as statistically significant $(\mathrm{p}=0.039)$. Hypocalcemia was higher after phototherapy. Whereas, mean $\mathrm{Mg}$ was $2.25 \pm 0.32 \mathrm{mg} / \mathrm{dl}$ pre-phototherapy and was $2.03 \pm 0.38 \mathrm{mg} / \mathrm{dl}$ post-phototherapy. The difference was as statistically significant $(\mathrm{p}<0.001)$. Mg level was lower after phototherapy. Pre-phototherapy, $11(22.0 \%)$ showed hypo and $39(78.0 \%)$ showed normal. Post-phototherapy, 17 (34.0\%) showed hypo and $33(66.0 \%)$ showed normal. The difference was as statistically non-significant $(\mathrm{p}=0.238)$.
\end{abstract}

Conclusion: Hypocalcemia is a common complication of phototherapy whereas hypomagnesaemia cannot be considered as a complication of phototherapy.

Keywords: Phototherapy, Hyperbilirubinemia, Calcium, Magnesium.

\section{INTRODUCTION}

Hyperbilirubinemia is the most common abnormal physical finding in the first week of life and is observed in approximately $60 \%$ of term infants and $80 \%$ of preterm infants ${ }^{(\mathbf{1})}$. Kernicterus is a devastating and disabling neurologic disorder characterized by the following clinical tetrad: choreoathetoid cerebral palsy, high-frequency sensorineural hearing loss, palsy of vertical gaze, and dental enamel hypoplasia. Kernicterus is a pathologic diagnosis, describing the yellow discoloration of the deep nuclei of the brain ${ }^{(2)}$.

Phototherapy has been the therapy of choice for neonates suffering from indirect hyperbilirubinemia. It reduces the plasma levels of unconjugated bilirubin, preventing kernicterus and decreasing the need for exchange transfusion ${ }^{(3)}$. Phototherapy has some complications such as insensible water loss, mutation and DNA strand break, hyperthermia, tremors, retinal damage, bronze baby syndrome, and affection of maternal-infant interaction ${ }^{(4)}$. One of the complications of phototherapy in neonates includes hypocalcemia and hypomagnesaemia ${ }^{(5)}$. The mechanism of hypocalcemic effect of phototherapy was reported by inhibition of pineal gland via transcranial illumination, resulting in decline of melatonin secretion, which blocks the effect of cortisol on bone calcium. Cortisol has a direct hypocalcemic effect and increases bone uptake of calcium and induces hypocalcemia ${ }^{(6)}$.

Magnesium plays a role in protecting the neural system against hypoxia and neurotoxic effects of bilirubin, through blocking N-methyl-D-aspartate receptor) NMDA receptor. Magnesium ion is one of the most important complex antagonist regulators of bilirubin molecule/ionic canal/NMDA receptor in humans. Bilirubin leads to hyperactivity of the NMDA receptor and exerts neurotoxic effects through binding to NMDA, which has a key role in synaptic physiologic functions and memory ${ }^{(7)}$.

The signs of disorder in magnesium and calcium are, to some extent, similar. In the recent years, limited research showed that phototherapy should be considered as a risk factor for hypocalcemia ${ }^{(8)}$. Hypocalcemia is defined as total serum calcium concentration of $<7 \mathrm{mg} / \mathrm{dl}(1.75 \mathrm{mmol} / \mathrm{L})$ in preterm and serum calcium $<8 \mathrm{mg} / \mathrm{dl}(2 \mathrm{mmol} / \mathrm{L})$ in term neonates. It can cause serious complications like neuromuscular irritability; myoclonic jerks, jitteriness, convulsion, cyanosis, apnea and laryngospasm. Moreover, cardiac manifestations like tachycardia, heart failure, prolonged QT interval and decreased contractibility are also seen due to hypocalcemia ${ }^{(9)}$. 
Hypomagnesemia is usually seen as any value $<0.66 \mathrm{mmol} / \mathrm{L}(1.6 \mathrm{mg} / \mathrm{dL})$. However, clinical signs do not manifest until levels drop below $0.5 \mathrm{mmol} / \mathrm{L}(1.2$ $\mathrm{mg} / \mathrm{dL})^{(2)}$. Phototherapy caused hypocalcemia can be prevented by covering the head (wearing a hat) during phototherapy. Although, these studies was conducted on full-term neonates, it seems logical to apply the hat on preterm neonates as well as the incidence of the phototherapy-induced hypocalcemia is higher in the latter than in full-term neonates. This may be due to the higher penetration of light in preterm neonates ${ }^{(8)}$.

This work aimed to study the effect of phototherapy on serum calcium and magnesium levels in neonates with unconjugated hyperbilirubinemia.

\section{PATIENTS AND METHODS}

The present study was conducted on 50 fullterm jaundiced neonates ( 23 males \& 27 females, gestational age $>37$ weeks \& weight $>2500$ gram and age under 4 weeks.). They received phototherapy for treatment of neonatal indirect hyperbilirubinemia. Cases were selected from those admitted to NICU of Benha University Hospital with their parents' consent.

\section{Exclusion criteria:}

Subjects with conjugated hyperbilirubinemia and perinatal asphyxia (Apgar $<4$ at 1 minute of birth). Those who fed with cow's milk, who had exchange transfusion, sepsis, babies born with apparent major congenital anomalies and those of mothers receiving $\mathrm{Mg}$ sulfate or oxytocin before delivery. Also, whose mothers had history of taking anti-convulsants were excluded from the study.

The data were collected in two phases. First, the information was obtained from the subjects' files, examination, and interview with the mothers. In the second phase, the laboratory data of the subjects were obtained during the treatment, before phototherapy and 48 hours after phototherapy. At the end of phototherapy blood samples were collected and complete blood count, bilirubin (with photometric method using dichlorophenyl diazonium salts), coombs test, reticulocytes count, calcium (with photometric method using cresolphthalein complexone) and magnesium (with photometric method using xylidyl blue). To perform phototherapy, the subjects were placed at a distance of 45 to 50 centimeters from the light source (eight blue fluorescent lights) with a wave-length range of 420 to $470 \mathrm{~nm}$ above their heads. The position of the baby was changed from time to time. Also, a fiber optics blanket specific to phototherapy was put under their bodies and eyes and genitals were completely covered. After completing the tests, the required information was collected and recorded.

\section{Ethical consent:}

An approval of the study was obtained from Benha University Academic and Ethical Committee. Every patient' parent signed an informed written consent for acceptance of the study. This work has been carried out in accordance with The Code of Ethics of the World Medical Association (Declaration of Helsinki) for studies involving humans.

\section{Statistical analysis}

The collected data were coded, processed and analyzed using the SPSS (Statistical Package for Social Sciences) version 22 for Windows ${ }^{\circledR}$ (IBM SPSS Inc, Chicago, IL, USA). Data were tested for normal distribution using the Shapiro Walk test. Qualitative data were represented as frequencies and relative percentages. Chi square test $(\chi 2)$ was used to calculate the difference between two or more groups of qualitative variables. Quantitative data were expressed as mean \pm SD (Standard deviation). Independent samples t-test was used to compare between two independent groups of normally distributed variables (parametric data). $\mathrm{P}$ value $\leq 0.05$ was considered significant.

\section{RESULTS}

The present study included 50 full term neonates who suffered from neonatal hyperbilirubinemia (23 males and 27 females). All neonates presented to NICU of Benha University Hospital.

Table (1): Distribution of the studied cases according to demographic data of cases $(n=50)$

\begin{tabular}{|c|c|c|}
\hline & No. & $\%$ \\
\hline Age (days) & & \\
\hline 1 & 7 & 14.0 \\
\hline 2 & 19 & 38.0 \\
\hline 3 & 13 & 26.0 \\
\hline 4 & 11 & 22.0 \\
\hline Mean \pm SD. & $2.56 \pm 0.99$ \\
\hline Median (IQR) & $2.0(2.0-3.0)$ \\
\hline Gestational age (weeks) & \multicolumn{2}{|c|}{} \\
\hline Mean \pm SD. & $39.20 \pm 0.93$ \\
\hline Median (IQR) & $39.0(38.0-40.0)$ \\
\hline Weight (kg) & \multicolumn{2}{|c|}{} \\
\hline Mean \pm SD. & $3.35 \pm 0.31$ \\
\hline Median (IQR) & $3.40(3.0-3.50)$ \\
\hline Height (cm) & \multicolumn{2}{|c|}{$50.58 \pm 0.98$} \\
\hline Mean \pm SD. & $50.50(50.0-51.0)$ \\
\hline Median (IQR)
\end{tabular}

IQR: Inter quartile range

SD: Standard deviation

Table (1) showed that mean gestational age was $39.20 \pm 0.93$ weeks and mean age was $2.56 \pm 0.99$ days, where $19(38.0 \%)$ were 2 days, $13(26.0 \%)$ were 3 days, $11(22.0 \%)$ were 4 days, and only $7(14.0 \%)$ were 1 day. In addition, mean weight was $3.35 \pm 0.31 \mathrm{~kg}$, and mean height was $50.58 \pm 0.98 \mathrm{~cm}$. 
Table (2): Distribution of the studied cases according to clinical data $(\mathrm{n}=50)$

\begin{tabular}{|l|c|c|}
\hline & No. & $\%$ \\
\hline Symptomatic (JITERNESS) & & \\
\hline No & 36 & 72.0 \\
\hline Yes & 14 & 28.0 \\
\hline $\begin{array}{l}\text { Respiratory } \\
\text { (number/minute) }\end{array}$ & \\
\hline Mean \pm SD. & $45.58 \pm 3.43$ \\
\hline Median (IQR) & $46.0(45.0-48.0)$ \\
\hline Heart rate (number/minute) & $138.70 \pm 4.97$ \\
\hline Mean \pm SD. & 140.0 \\
\hline Median (IQR) & $(135.0-143.0)$ \\
\hline Temperature $\left.\mathbf{~}^{\mathbf{}} \mathbf{C}\right)$ & $35.68 \pm 0.17$ \\
\hline Mean \pm SD. & 36.65 \\
\hline Median (IQR) & $(36.50-36.80)$ \\
\hline Blood pressure (mmHg) & \\
\hline Systole & $76.70 \pm 4.20$ \\
\hline Mean \pm SD. & $76.0(75.0-80.0)$ \\
\hline Median (IQR) & \\
\hline Diastole & $45.6(45.0-48.0)$ \\
\hline Mean \pm SD.
\end{tabular}

Table (2) showed that $14(28.0 \%)$ showed symptomatic (JITERNESS), mean respiratory rate was $45.58 \pm 3.43$, mean heart rate was $138.70 \pm 4.97$, mean temperature was $35.68 \pm 0.17$, and mean blood pressure was $76.70 \pm 4.20 / 45.68 \pm 3.55$ (systolic/diastolic).

Table (3): Comparison between pre-phototherapy and post-phototherapy concerning $\mathrm{Ca}(\mathrm{n}=50)$

\begin{tabular}{|c|c|c|c|c|c|c|}
\hline \multirow[t]{2}{*}{ Ca } & \multicolumn{2}{|c|}{$\begin{array}{c}\text { Pre } \\
\text { phototherapy }\end{array}$} & \multicolumn{2}{|c|}{$\begin{array}{c}\text { Post } \\
\text { phototherapy }\end{array}$} & \multirow{2}{*}{$\begin{array}{l}\text { Test } \\
\text { of } \\
\text { sig. }\end{array}$} & \multirow{2}{*}{$\mathbf{p}$} \\
\hline & No. & $\%$ & No. & $\%$ & & \\
\hline $\begin{array}{c}\text { Hypo- } \\
\text { calcemia } \\
(<8 \mathrm{mg} / \mathrm{dl})\end{array}$ & 12 & 24.0 & 19 & 38.0 & \multirow{2}{*}{$\begin{array}{c}x^{2}= \\
2.291\end{array}$} & \multirow{2}{*}{$\begin{array}{l}\mathrm{McN}_{\mathrm{P}}= \\
0.039^{*}\end{array}$} \\
\hline $\begin{array}{l}\text { Normal } \\
\text { calcium } \\
(>8 \mathrm{md} / \mathrm{dl})\end{array}$ & 38 & 76.0 & 31 & 62.0 & & \\
\hline $\begin{array}{l}\text { Mean } \pm \\
\text { SD. }\end{array}$ & \multicolumn{2}{|c|}{$8.63 \pm 1.54$} & \multicolumn{2}{|c|}{$8.22 \pm 1.64$} & \multirow{2}{*}{$\begin{array}{c}t= \\
4.300^{*}\end{array}$} & \multirow{2}{*}{$<0.001^{*}$} \\
\hline $\begin{array}{c}\text { Median } \\
(\mathrm{IQR})\end{array}$ & \multicolumn{2}{|c|}{$\begin{array}{c}8.95(8.10 \\
-9.60)\end{array}$} & \multicolumn{2}{|c|}{$\begin{array}{c}8.50(7.30 \\
-9.20)\end{array}$} & & \\
\hline
\end{tabular}

$\chi^{2}$ : Chi square test; McN: McNamara test; t: Paired t-test ; $\mathrm{p}$ : $\mathrm{p}$ value for comparing between pre and post; *: Statistically significant at $\mathrm{p} \leq 0.05$; IQR: Inter quartile range ;SD: Standard deviation

Table (3) showed that mean calcium was $8.63 \pm$ 1.54 pre-phototherapy and was $8.22 \pm 1.64 \mathrm{mg} / \mathrm{dl}$ postphototherapy. The difference was as statistically significant $(\mathrm{p}<0.001)$. Calcium level was lower after phototherapy.
Pre-phototherapy, $12 \quad(24.0 \%)$ showed hypocalcemia $(<8 \mathrm{mg} / \mathrm{dl})$ and $38(76.0 \%)$ showed normal calcium (> $8 \mathrm{md} / \mathrm{dl})$. Post-phototherapy, 19 $(38.0 \%)$ showed hypocalcemia $(<8 \mathrm{mg} / \mathrm{dl})$ and $31(62.0$ $\%$ ) showed normal calcium (> $8 \mathrm{md} / \mathrm{dl})$. The difference was statistically significant $\left(\mathrm{p}=0.039^{*}\right)$. Hypocalcemia was higher after phototherapy.

Table (4): Comparison between pre phototherapy and post phototherapy regarding $\mathrm{Mg}(\mathrm{n}=50)$

\begin{tabular}{|c|c|c|c|c|c|c|}
\hline \multirow{2}{*}{ Mg } & \multicolumn{2}{|c|}{\begin{tabular}{|c|} 
Pre \\
phototherapy
\end{tabular}} & \multicolumn{2}{|c|}{\begin{tabular}{|c} 
Post \\
phototherapy
\end{tabular}} & \multirow{2}{*}{$\begin{array}{c}\text { Test } \\
\text { of } \\
\text { sig. }\end{array}$} & \multirow{2}{*}{$\mathbf{P}$} \\
\hline & No. & $\%$ & No. & $\%$ & & \\
\hline Нуро & 11 & 22.0 & 17 & 34.0 & \multirow{2}{*}{$\begin{array}{c}x^{2}= \\
1.78 \\
6\end{array}$} & \multirow[b]{2}{*}{$\begin{array}{l}\mathrm{McN}_{\mathrm{P}}= \\
0.238\end{array}$} \\
\hline $\begin{array}{c}\text { Normal } \\
(1.8- \\
2.5) \\
\end{array}$ & 39 & 78.0 & 33 & 66.0 & & \\
\hline $\begin{array}{l}\text { Mean } \pm \\
\text { SD. }\end{array}$ & \multicolumn{2}{|c|}{$2.25 \pm 0.32$} & \multicolumn{2}{|c|}{$2.03 \pm 0.38$} & \multirow{2}{*}{$\begin{array}{c}\mathrm{t}= \\
4.98 \\
6^{*}\end{array}$} & \multirow{2}{*}{$\begin{array}{l}<0.00 \\
1^{*}\end{array}$} \\
\hline $\begin{array}{l}\text { Median } \\
\text { (IQR) }\end{array}$ & \multicolumn{2}{|c|}{$\begin{array}{c}2.30(2.10- \\
2.50)\end{array}$} & \multicolumn{2}{|c|}{$\begin{array}{c}2.0(1.70- \\
2.30)\end{array}$} & & \\
\hline
\end{tabular}

$\chi^{2}$ : Chi square test ; cN: McNamara test; $t$ : Paired t-test ; $\mathrm{p}$ : $\mathrm{p}$ value for comparing between pre and post; *: Statistically significant at $\mathrm{p} \leq 0.05$; IQR: Inter quartile range; $\mathrm{SD}$ : Standard deviation

Table (4) summarized comparison between prephototherapy and post-phototherapy according to $\mathrm{Mg}$ (n $=50$ ). Mean $\mathrm{Mg}$ was $2.25 \pm 0.32$ pre-phototherapy and was $2.03 \pm 0.38 \mathrm{mg} / \mathrm{dl}$ post-phototherapy. The difference was as statistically significant $(\mathrm{p}<0.001)$. $\mathrm{Mg}$ level was lower after phototherapy.

Pre-phototherapy, 11 (22.0\%) showed hypo and $39(78.0 \%)$ showed normal. Post-phototherapy, 17 (34.0\%) showed hypo and $33(66.0 \%)$ showed normal. The difference was statistically non-significant $(\mathrm{p}=$ $0.238)$.

Table (5): Relation between Ca (post) and Duration of phototherapy $(n=50)$

\begin{tabular}{|c|c|c|c|c|}
\hline \multirow{2}{*}{$\begin{array}{l}\text { Duration of } \\
\text { phototherapy }\end{array}$} & \multicolumn{2}{|c|}{$\begin{array}{c}\text { Ca (post } \\
\text { phototherapy) }\end{array}$} & \multirow[b]{2}{*}{$\mathbf{U}$} & \multirow[b]{2}{*}{$\mathbf{P}$} \\
\hline & $\begin{array}{c}\text { Hypocalcemia } \\
(n=19)\end{array}$ & $\begin{array}{l}\text { Normal } \\
\text { calcium } \\
(\mathbf{n}=31)\end{array}$ & & \\
\hline Mean \pm SD & $4.26 \pm 1.19$ & $\begin{array}{c}3.03 \pm \\
0.91\end{array}$ & \multirow{2}{*}{$131.0^{*}$} & \multirow{2}{*}{$<0.001$} \\
\hline Median & 4.0 & 3.0 & & \\
\hline
\end{tabular}

U: Mann Whitney test; $\mathrm{p}: \mathrm{p}$ value for association between different categories; *: Statistically significant at $\mathrm{p} \leq 0.05$

Table (5) summarized the relation between $\mathrm{Ca}$ (post) and duration of phototherapy $(\mathrm{n}=50)$. There was a statistically significant relation $\mathrm{Ca}$ (post) and duration of phototherapy $(\mathrm{p}<0.001)$. Duration of phototherapy was lower in normal calcium than hypocalcemia. 
Table (6): Relation between $\mathrm{Mg}$ (post) and duration of phototherapy $(\mathrm{n}=50)$

\begin{tabular}{|c|c|c|c|c|}
\hline \multirow{2}{*}{$\begin{array}{l}\text { Duration of } \\
\text { phototherapy }\end{array}$} & \multicolumn{2}{|c|}{$\begin{array}{c}\text { Mg } \\
\text { (post phototherapy) }\end{array}$} & \multirow[b]{2}{*}{$\mathbf{U}$} & \multirow[b]{2}{*}{$\mathbf{p}$} \\
\hline & $\begin{array}{c}\text { Hypo- } \\
\text { calcemia } \\
(\mathbf{n}=\mathbf{1 7})\end{array}$ & $\begin{array}{l}\text { Normal } \\
\text { calcium } \\
(\mathrm{n}=\mathbf{3 3})\end{array}$ & & \\
\hline $\begin{array}{c}\text { Mean } \pm \\
\text { SD. }\end{array}$ & $3.65 \pm 0.06$ & $\begin{array}{c}3.42 \pm \\
0.25\end{array}$ & \multirow[t]{2}{*}{238.50} & \multirow[t]{2}{*}{0.372} \\
\hline Median & 4.0 & 3.0 & & \\
\hline
\end{tabular}

SD: Standard deviation ; U: Mann Whitney test; $\mathrm{p}$ : $\mathrm{p}$ value for association between different categories

Table (6) summarized the relation between $\mathrm{Mg}$ (post) and duration of phototherapy $(n=50)$. There was a statistically non-significant relation between $\mathrm{Mg}$ (post) and duration of phototherapy $(\mathrm{p}=0.372)$.

\section{DISCUSSION}

Neonatal hyperbilirubinemia nearly affects $60 \%$ of term and $80 \%$ of preterm neonates during first week of life. $6.1 \%$ of well-term newborn have a serum bilirubin over $12.9 \mathrm{mg} \%$. Serum bilirubin over $15 \mathrm{mg} \%$ is found in $3 \%$ of normal term newborns ${ }^{(10)}$. Bilirubin is the catabolic product of heme metabolism. Within physiologic range, bilirubin has cytoprotective and beneficial metabolic effects, but in high levels it is potentially toxic. Fortunately, there are elaborate physiologic mechanisms for its detoxification and disposition. Understanding these mechanisms is necessary for interpretation of the clinical significance of high serum bilirubin concentrations ${ }^{(11)}$.

The accumulation of bilirubin manifests as yellow discoloration of the skin, sclera, and mucosa that is called jaundice. Neonates with severe hyperbilirubinemia (defined as a TSB $>25 \mathrm{mg} / \mathrm{dL}$ in late preterm and term infants) are at risk for bilirubininduced neurologic dysfunction (BIND), which occurs when bilirubin crosses the blood-brain barrier and binds to targeted brain tissues. Hyperbilirubinemia presents as either unconjugated hyperbilirubinemia or conjugated hyperbilirubinemia. The 2 forms involve different causes and complications. In contrast to unconjugated hyperbilirubinemia, which can be transient and physiologic in the newborn period, conjugated hyperbilirubinemia is always pathologic and requires thorough investigations (2). Chronic bilirubin encephalopathy (kernicterus) is a devastating and disabling neurologic disorder characterized by the following clinical tetrad: choreoathetoid cerebral palsy, high-frequency sensorineural hearing loss, palsy of vertical gaze, and dental enamel hypoplasia. Kernicterus is a pathologic diagnosis, describing the yellow discoloration of the deep nuclei of the brain. Brain regions that are typically affected are the globus pallidus, subthalamic nucleus, metabolic sector of the hippocampus, oculomotor nuclei, ventral cochlear nuclei, and Purkinje cells of the cerebellar cortex ${ }^{(2)}$.
Phototherapy is the first step in the management of raised unconjugated jaundice in newborn infants. It is a safe and convenient method of lowering serum bilirubin levels and reduces the need for more invasive treatment, exchange transfusion ${ }^{(\mathbf{1 2})}$.

Abnormalities of magnesium $\left(\mathrm{Mg}^{2+}\right)$ and calcium $\left(\mathrm{Ca}^{2+}\right)$ metabolism are commonly seen in the neonatal intensive care unit. Calcium disturbances may be mirrored by magnesium, seen as hypocalcemia with hypomagnesaemia or hypercalcemia with hypermagnesemia. Abnormalities in serum values for $\mathrm{Ca}^{2+}$ and $\mathrm{Mg}^{2+}$ are of concern in any infant and warrant further investigation ${ }^{(2)}$.

In our study, jaundiced neonates treated with phototherapy with mean total bilirubin of $18.39 \pm 2.27$ $\mathrm{mg} / \mathrm{dl}$ included 50 neonates; 23males (46\%) and 27 females $(54 \%)$ with mean gestational age of $39.20 \pm$ 0.93 weeks and mean phototherapy duration of $3.5 \pm$ 1.18 days.

In our study, hypocalcemia was assessed as a complication of phototherapy in newborns managed for neonatal hyperbilirubinemia as mean calcium was 8.63 \pm 1.54 pre-phototherapy and was $8.22 \pm 1.64 \mathrm{mg} / \mathrm{dl}$ post-phototherapy. The difference was as statistically significant $(\mathrm{p}<0.001)$. Calcium level was lower after phototherapy. Pre-phototherapy, $12(24.0 \%)$ showed hypocalcemia $(<8 \mathrm{mg} / \mathrm{dl})$ and $38(76.0 \%)$ showed normal calcium (> $8 \mathrm{md} / \mathrm{dl}$ ). Post-phototherapy, 19 $(38.0 \%)$ showed hypocalcemia $(<8 \mathrm{mg} / \mathrm{dl})$ and $31(62.0$ $\%)$ showed normal calcium $(>8 \mathrm{md} / \mathrm{dl})$. The difference was statistically significant $\left(\mathrm{p}=0.039^{*}\right)$. Hypocalcemia was higher after phototherapy however 14 (28\%) showed symptoms (Jitteriness).

On the same aspect relation between $\mathrm{Ca}$ (post) and duration of phototherapy $(n=50)$, there was a statistically significant relation between $\mathrm{Ca}$ (pre) and duration of phototherapy $(\mathrm{p}<0.001)$. Duration of phototherapy was lower in normal calcium than in hypocalcemia. To prevent hypocalcemia within phototherapy, there are two suggestions: 1- oral calcium supplementation during phototherapy, 2- covering head during phototherapy in order to prevent reaching of light to the pineal gland and prevention of melatonin reduction, which eventually leads to the prevention of hypocalcemia ${ }^{(\mathbf{1 3})}$.

Whereas, mean $\mathrm{Mg}$ was $2.25 \pm 0.32$ prephototherapy and was $2.03 \pm 0.38 \mathrm{mg} / \mathrm{dl}$ postphototherapy. The difference was as statistically significant $(\mathrm{p}<0.001) . \mathrm{Mg}$ level was lower after phototherapy. Pre-phototherapy, $11(22.0 \%)$ showed hypomagnesaemia and $39(78.0 \%)$ showed normal. Post-phototherapy, $17 \quad(34.0 \quad \%)$ showed hypomagnesaemia and 33 (66.0\%) showed normal. The difference was as statistically non-significant $(\mathrm{p}=$ 0.238).

Also, Tehrani et al. ${ }^{(14)}$ noticed that the effect of phototherapy on serum level of calcium and magnesium in infants with jaundice at Mostafa Khomeini Hospital, Tehran, Iran. Results of study showed that the level of 
calcium in term infants undergoing phototherapy with average of $9.51 \mathrm{mg} / \mathrm{dL}$ that was less than that of the hospitalization time with an average of $9.85 \mathrm{mg} / \mathrm{dL}$ and this decrease was statistically significant similar to the results of our study.

Regarding serum level of magnesium in the study, the average was $2.06 \pm 0.39 \mathrm{mg} / \mathrm{dL}$ after phototherapy, which was less than that of the hospitalization time $(2.21 \pm 0.57 \mathrm{mg} / \mathrm{dL})$ and this decrease is not compatible with our study, in which the difference of serum magnesium before and after phototherapy was statistically non-significant ${ }^{(\mathbf{1 4})}$. Also, the outcomes of the our study are in accordance with those of the investigations by Singh et al. ${ }^{(15)}$ that showed after 48 hour phototherapy a significant fall in calcium level in $30 \%$ of term \& $70 \%$ of preterm neonates was observed. Also Jain ${ }^{(16)}$ found that $35 \%$ of preterm and $39 \%$ of full-term infants developed hypocalcaemia.

\section{CONCLUSION}

We conclude that hypocalcemia is a common complication of phototherapy whereas hypomagnesaemia cannot be considered as a complication of phototherapy.

\section{Financial support and sponsorship: Nil.}

\section{Conflict of interest: Nil.}

\section{REFERENCES}

1. Stoll B, Piazza A (2007): Jaundice and hyperbilirubinemia in the newborn. Nelson Text Book of Pediatrics, 9: 603-12.

2. Gomella T, Fabien G, Mohammed F (2020): Hyperbilirubinemia: Unconjugated, Gomella's Neonatology Management, 8 edition Procedures, On-Call Problems, Diseases, and Drugs. London. New York MC Graw Hill Education. Pp: 663685.https://accesspediatrics. mhmedical. com/content. asp $x$ ?bookid $=2762 \&$ sectionid $=234453147$

3. Faulhaber F, Procianoy R, Silveira R (2019): Side effects of phototherapy on neonates. American Journal of Perinatology, 36 (03): 252-257.

4. Martin C, Cloherty J (2008): Neonatal hyperbilirubinemia. In: Manual of Neonatal Care 6th ed. Cloherty JP, Eichenwald EC, Stark AR, eds, Philadelphia: Lippincott Williams \& Wilkins, Pp: 181212.
5. Behrman R, Vaughan $V$ (2004): Jaundice and hyperbilirubinemia in the newborn infant, Nelson textbook of pediatrics. WB Saunders Company, Pp: 189227.

6. Goyal S, Srivastava A, Bhattacharjee P et al. (2018): Effect of phototherapy on serum calcium levels in neonates receiving phototherapy for neonatal jaundice. Int J Res Med Sci., 6 (6): 1992-5.

7. Imani M, Rezaee-pour M, Mohamdi M et al. (2012): Study of relationship between total Magnesium and total bilirubin levels in neonates' sera before and after phototherapy. Razi Journal of Medical Sciences, 19 (100): 54-61.

8. Kargar M, Jamshidi Z, Beheshtipour N et al. (2014): Effect of head covering on phototherapy-induced hypocalcaemia in icterus newborns; a randomized controlled trial. International Journal of Community Based Nursing and Midwifery, 2 (2): 121-23.

9. Gregory M, Martin C, Cloherty J (2012): Neonatal Hyperbilirubinemia. In: Cloherty JP, Eichenwald EC, Hansen AR, Stark AR (eds.) Manual of neonatal care. 7th ed. Philadelphia: Lippincott Willams and Wilkins, Pp: 304-339.

10. MacDonald M, Seshia M (2015): Avery's neonatology: pathophysiology and management of the newborn. Lippincott Williams \& Wilkins, Pp: 58-81. https://www.amazon.com/Averys-Neonatology-

Pathophysiology-Management-

Pathophusiology/dp/1451192681

11. Erlinger S, Arias I, Dhumeaux D (2014): Inherited disorders of bilirubin transport and conjugation: new insights into molecular mechanisms and consequences. Gastroenterology, 146 (7): 1625-38.

12. Mitra S, Rennie J (2017): Neonatal jaundice: aetiology, diagnosis and treatment. British Journal of Hospital Medicine, 78 (12): 699-704.

13. Samane Z, Minoo M (2016): The effect of covering head on the hypocalcemia caused by phototherapy in the icteric preterm infants in the Valie-Asr Hospital in 2015: a randomized controlled trial. Intl J Med Res Health Sci., 5: 138-42.

14. Tehrani F, Davati A, Ansari I et al. (2018): Effect of phototherapy on serum level of calcium, magnesium and vitamin $\mathrm{D}$ in infants with hyperbilirubinemia. Iranian Journal of Pathology, 13 (3): 357-362.

15. Singh P, Chaudhuri P, Chaudhuri A (2017): Phototherapy induced hypocalcemia in neonatal hyperbilirubinemia. IOSR-JDMS., 16: 35-8.

16. Jain S (2015): Evaluation of effect of phototherapy on serum calcium level. Medpulse-International Med J., 2 (6): 316-8. 